\title{
The Anthropology of Money and Finance: Between Ethnography and World History
}

Keith Hart, London School of Economics and University of Pretoria, johnkeithhart@gmail.com Horacio Ortiz, Centre de Sociologie de l'Innovation, Mines ParisTech, CNRS UMR 7185, horacio.ortiz@free.fr

\section{$\underline{\text { Abstract: }}$}

We review here recent developments in the anthropology of money and finance, listing its achievements, shortcomings and prospects, while referring back to the discipline's founders a century ago. We take our departure from the work of Marcel Mauss and Karl Polanyi, both of whom combined openness to ethnographic research with a vision of world history as a whole. Since the 1960s, anthropologists have tended to restrict themselves to niche fields and marginal debates. From the 1980s the anthropological study of money and ethnographies of finance especially have taken off. Despite taking on new objects and directions, anthropologists still find it difficult to connect their situated analyses with global processes and world history. We propose some conceptual and empirical directions for research that would seek to overcome these limitations by integrating ethnography more closely with human history, while stressing the importance of money in shaping world society and in attempts to reform it.

Keywords: distribution, economic anthropology, exchange, globalization, politics, world society 
Table of Contents:

\section{Introduction}

\section{Money and finance: anthropology's classical legacy}

Mauss: money and credit as the basis of human identity and for an expanded society

Marx, Weber and Simmel: grand narratives of capitalist globalization

Karl Polanyi and the politics of distribution

\section{Contemporary research in the anthropology of money and finance}

What is money? Where does it come from?

Grand narratives in current research on money and finance

The ethnography of finance and the politics of distribution

Bringing world history back in

The way forward for an anthropology of money and finance

The need to combine fieldwork methods with historical study of global processes

States, corporations and regional associations

Finance, communications technologies and new forms of money

Money in the making of society at all levels

\section{Introduction}

There is much talk today of a financial and economic crisis comparable to the 1930s. With the threat of a currency war and the euro's collapse looming, the specter of the Great Depression's bloody aftermath has returned with a vengeance. Several versions of how to make human beings and build society co-existed during the Cold War, when much of the world won independence from colonial empire. Yet, discussion of humanity's growing interdependence is today limited to a one-world capitalism driven by finance. What have 
anthropologists to say about that? It would seem very little. But a positive case can be made for the discipline's contribution to public debate. We make such a case here.

We review recent developments in the anthropology of money and finance, listing its achievements, shortcomings and prospects, while referring back to the discipline's founders a century ago. Economic anthropologists have tended to restrict themselves to niche fields and marginal debates since the 1960s. We hope to reverse this trend by focusing on money's role in shaping global society and bringing world history into a more active dialogue with ethnography.

Money and finance have been prominent in anthropology since its formation as a modern discipline. Rather than emphasize what money does, as the economists do -- a medium of exchange, reserve fund or means of accounting - anthropologists can approach it as an integral part of the hierarchies and networks of exchange through which it circulates. Its multiple meanings in turn keep society together and reinforce the roles played by each member. Money's capacity to transcend group boundaries drives the extension of society to more inclusive levels and transforms identities in the process. It is a commonplace for our discipline to show that money's meanings and relations cannot be confined a single theory.

Fieldwork-based ethnography - a commitment to joining the people where they live in order to discover what they do and think - was the principal achievement of twentieth-century anthropology; but it is insufficient for studying money (Hart 1986). The ethnographic revolution eventually removed world history from twentieth-century anthropologists' repertoire. This is hardly conducive to the task of investigating money's global role in our historical moment. Progress in economic anthropology depends on combining ethnography and world history within a critical perspective (Hann \& Hart 2011). 
So our trademark research method reaches a limit when we try to understand money's global circulation today. It would help too if anthropologists were aware of developments in relevant outside disciplines and of contemporary currents of world history that shape how we think. When it comes to money, this means having some knowledge of the history of monetary economics and a perspective on global finance. If the new ethnography of finance is to throw more than superficial light on society, we must transcend the categories that shape media discussion of the "crisis" and try to understand our shared human predicament as a moment in the history of money.

We need new methods if we wish to account for how money underpins social identities and relations of conflict, hierarchy and interdependence in the world we are making today. This review proposes some of the tools we need, drawing first on some classical authors who combined openness to ethnographic discovery with a global vision of economic history in their times and then on contemporary anthropological research.

In Part 1, we consider the main social theories of money a century ago, when it was seen to shape the constitution of nation states, capitalist bureaucracy and colonial empire. Marx, Simmel and Weber aspired to develop a general theory of money, whereas Mauss and Polanyi emphasized money's multiple meanings. This allowed them not only to account for a variety of monetary arrangements, but also to avoid thinking of history in teleological terms and to embrace money's plasticity as a tool for social transformation.

In Part 2, we assess anthropologists' achievements since the 1980s. Not only has money come to be seen in a more constructive light, but its variability has been widely acknowledged. With one or two notable exceptions, however, anthropologists have found it hard to link their detailed ethnographic accounts to world history in the longer run. Some still restrict their analyses to observable situations, whether these be personal interactions or 
organizational spaces, like offices and street markets. Even when anthropologists highlight the political relevance of their findings, they do not directly study global flows of money and the historical situation surrounding them. A few address the larger picture, but they tend to do so from on high without ever touching the ground, which only repeats the model of writing grand theories whose limitations have been well-exposed before.

In our concluding section, we identify some moves that might help anthropology to illuminate money's role in constituting world society today. Nostrums inherited from the Cold War era, such as neo-liberalism, Marxism or post-colonial theory, will not do the job. If anthropologists were to recognize money's potential to transform both world society and every one of us, we could not only think about the past and present, but also contemplate the future. We will not get far as isolated individuals or by denying the need for interdisciplinary collaboration. But harnessing the example of inspiring ancestors to contemporary conditions of possibility offers a good place to start.

\section{Money and finance: anthropology's classical legacy}

Sociology and anthropology emerged as part of a drive to understand and explain how industrialization was changing the West's place in world history. Of all the important works produced during that time, we highlight Marcel Mauss's contribution as being especially relevant since he showed how money was fundamental to how we form distinct aspects of our social identities, without trying to fit them into a unitary theory of money. He mobilized world history to highlight power relations in the industrial societies of his time, while showing how monetary relations extended societies beyond their pretensions to selfsufficiency and were a conspicuous means of their transformation. Mauss stands out in this respect when contrasted with Karl Marx, Max Weber, and Georg Simmel. It links him to Karl Polanyi who also studied monetary relations throughout world history in order to highlight 
the political plight of his times — the terrible decades of war and depression from 1914 to 1945. Polanyi traced these conflicts to the Victorians' utopian experiment in free markets, but also to the unequal distribution of wealth and how it might be redressed, a thrust that we hope to build on in charting a progressive path for contemporary anthropology.

\section{Mauss: money and credit as the basis of human identity and for an expanded society}

In his famous essay on The Gift, Marcel Mauss (1990 [1925]) showed how the concepts of freedom, justice and the person can only be understood within the specific monetary arrangements that give us our various social identities. Émile Durkheim (1960 [1893]) had demonstrated how a British emphasis on making private contracts in markets obscured the social glue of "the non-contractual element in the contract" that made the economy possible a combination of law, state, custom, morals and shared history that the sociologist must try to make more visible. Thus, monetary valuation is never just technical, but also moral, religious and political, signaling the symbolic position of each person in society according to various orders of reckoning.

The concept of persona evolved over time (Mauss 1985 [1938]) and with it so did the concept of society: both its inner rules and external boundaries were reshaped by monetary relations. Malinowski (1921) was adamant that the Trobriand kula valuables were not money in that they did not function as a medium of exchange and standard of value. But, in a long footnote, Mauss held out for a broader conception:

On this reasoning ... there has only been money when precious things ... have been really made into currency - namely have been inscribed and impersonalized, and detached from any relationship with any legal entity, whether collective or individual, 
other than the state that mints them ... One only defines in this way a second type of money - our own (Mauss 1990:127n).

He suggested that primitive valuables are like money in that they "have purchasing power and this power has a figure set on it" (ibid.). He also took Malinowski to task for reproducing the bourgeois contrast between commercial self-interest and the free gift, a dichotomy that many anthropologists have subsequently attributed to Mauss himself.

One of Mauss's key modifications to Durkheim's legacy was to conceive of society as a historical project of humanity whose limits were extended to become ever more inclusive. Society could not be taken for granted as a pre-existent form. It must be made and remade, sometimes from scratch. Gift-exchange pushes the limits of society outwards. "The whole intertribal kula is merely the extreme case ... of a more general system. This takes the tribe itself in its entirety out of the narrow sphere of its physical boundaries and even of its interests and rights.” (Mauss 1990: 36).

Mauss (1990) was enthusiastic about the publication of Argonauts of the Western Pacific, but he held that money and markets were human universals, whereas Malinowski $(1921,1922)$ went out of his way to oppose the kula ring to both. The impersonal economic forms found in capitalist societies were recent inventions, according to Mauss. They shared the world with many other ways to use money, even in Europe and North America, and were bound to be transformed in the future. For him, the socialist movement from below and the development of social protection in Europe were processes in this direction (1990).

Mauss's financial journalism, particularly concerning the exchange rate crisis of 1922-24, accounts for a fifth of his published political writings (Mauss 1997; Hart 2014), but he generally maintained a firewall between politics and his academic work (Fournier 2006, Hart 
2007). He broke this rule only once, in the concluding chapter to The Gift. An example of how far he was prepared to go politically may be found in an unpublished paper, "A means of overhauling society: the manipulation of currencies" (Fournier 2006: 212 and 390 n.105), where he claims, with a strong echo of Keynes, that the great economic revolutions are "monetary in nature" and the manipulation of currencies and credit could be a "method of social revolution ...without pain or suffering":

It suffices to create new monetary methods within the firmest, the narrowest bounds of prudence. It will then suffice to manage them with the most cautious rules of economics to make them bear fruit among the new entitled beneficiaries. And that is revolution. In this way the common people of different nations would be allowed to know how they can have control over themselves - without the use of words, formulas or myths. (Mauss, in Fournier, ibid.)

Mauss argued for a pragmatic understanding of the human economy that would be of use to people in their daily lives. Nearly a century later, we draw inspiration from him for a similar argument (Hart \& Maurer 2009; Hart, Laville \& Cattani 2010).

Marx, Weber and Simmel: grand narratives of capitalist globalization

In spite of his insights into world history and his analytical interest in the institutions governing money at the time, Mauss did not explore them in a systematic way, unlike many of his predecessors and contemporaries. Among these, Karl Marx, Max Weber and Georg Simmel stand out.

Marx (1977 [1869]) was the first economist to recognize the centrality of machine production for the modern economy. He believed that what matters in our societies are people, machines and money in that order; but money controlled the machines and through them most workers. 
His early slogan, "workers of the world unite" (Marx \& Engels 1987 [1848]), was intended to reverse that situation. In contrast to many on the left (and his Stalinist successors) who proposed a world without markets and money, Marx (1973 [1858]) put money at the center of any complex society, both actual and potential (Nishibe 2005). An apparently neutral instrument of exchange among equals in liberal theory, money acted also as a "fetish", both hiding and articulating hierarchical relations between the owners of the means of production and those whom they exploited (Marx 1977). He incorporated this insight into a historical synthesis of the relations and forces of production which would soon subject the whole world to capitalist expansion. Unlike Mauss, Marx did not expect to learn from other monetary arrangements, but rather expected the movement of resistance to capitalism's homogenizing logic that he and Engels built to become the horizon of all humanity.

In his Philosophy of Money (1978 [1900]), Simmel attempted to make sense of the unequal monetary relations of his time within a neo-Kantian project aiming at a society of equal and independent individuals. Money allowed for individual expression of desires and thus for the social constitution of an autonomous subject. But, because it only worked as a measure of value because people could count on others to accept it, money transcended the individual. Simmel identified money's twin anchors as its physical substance (coins, paper) and the community of its users which is an invisible third party to all transactions. He predicted that money's physical substance would wither away, thereby revealing its social character; indeed it is a symbol of our human capacity to make universal society. As capitalism and colonialism expanded, money would dialectically unite the world through common standards of measure, provoking general recognition that all participating subjects are intrinsically equal and thereby giving rise to a more just distribution of money than that proposed by capitalism. Simmel, in Hegelian fashion, understood the present as a moment in history that would be surpassed by its own teleology. 
Max Weber did not engage with world history as teleology, but his analytical categories closely reproduced the moral vision of neo-Kantianism. As we all know, for him the origins of modern capitalism lay in a religious revolution, the Reformation, whose cultural premises had an affinity with business enterprises' need for rational calculation (Weber 2003 [19041905]). He was also aware of the intimate links between bureaucracy, states and capitalist firms (Weber 2013 [1922]). Yet, whether discussing Chinese peasants or Protestant entrepreneurs, the personality structure of his ideal types does not change over time or between places. A subject always exercises free will in relation to different values through action of three types - habitual, affective and rational - that set the limits to what Weber's (1978 [1920]) sociology can account for. Money does not occupy a distinctive position within this framework, being generally a means of exchange which depends on trust between the participants. Thus, Weber's historical analysis of capitalism does not support a vision of an alternative future for humanity, but rather envisages the tragic repetition of the general types of human action.

\section{Karl Polanyi and the politics of distribution}

In The Great Transformation, Polanyi argued that "Actual money is merely a token of purchasing power which, as a rule, is not produced at all, but comes into being through the mechanism of banking or state finance" (2001 [1944]: 72). Money thus did not serve a specific function, but was on the contrary a product of the social relations it articulated. Consistent with this approach, Polanyi inverts the liberal myth of money's origin in barter: "Long-distance trade often engenders markets, an institution which involves acts of barter, and, if money is used, of buying and selling" (2001: 58). Money and markets thus extend society beyond its local core. This usually entails changes in society, especially distribution (who gets what), for which money is central. 
Polanyi distinguished between "token" and "commodity" forms of money. Token money was designed to facilitate domestic trade, commodity money foreign trade. Money was thus

...not a commodity, it was purchasing power; far from having utility itself, it was merely a counter embodying a quantified claim to things that could be purchased. Clearly, a society in which distribution depended on possession of such tokens of purchasing power was a construction entirely different from market economy (2001: 196).

Polanyi (2001) held that the utopian attempt to organize all social life as individualized and impersonal market relations, for which Britain from the late eighteenth century was the paradigmatic case, was the main cause of the inequality and broken social ties that led to the Second World War when he wrote his book. As society expanded through monetary relations, the tension between community and anonymity in economic transactions became intolerable. Markets had once been kept at arm's length from society, but they were now intrinsic to its internal functioning. The move to a welfare state was part of this history. But it implied new forms of sociality where the boundaries separating inside society from outside were increasingly called into question (Polanyi 2001).

Like Mauss, Polanyi explored money's constitutive role in framing the limits of sociality. He did not take money to be a set of eternal functions (Polanyi 1977 [1964]), nor did it play the same role in establishing power relations and social hierarchies across time and place. His vision may be understood as a critique of market economy, compatible in some ways with the Marxists'. But he wanted to show how various monetary arrangements correspond to different social configurations and that the current alliance between a powerful finance industry and nation-states must be seen in this light, especially if we wish to transform it. 
Rather than start, as economic liberals do, with a definition of money's functions and an ontology of the agents who use it, Mauss and Polanyi show how monetary relations are fundamental to the definition of self and society in specific settings,. These relations are potentially subversive, in that they challenge social rules and hierarchies, even the boundaries of society itself. The perspective on economy that prevails today represents our interdependent world's contradictions as being largely a conflict over credit and currency; but Mauss and Polanyi point to how anthropologists might help shape humanity's common future. In the major methodological debates of the 1960s and 70s, however, with Polanyi's (1957) active encouragement, anthropologists acquiesced in an academic division of labor that limited us to parochial debates and exotic objects of study (Hann \& Hart 2011). Although the anthropology of money and finance has been resurgent since the 1980s, we are still struggling with this limitation.

\section{Contemporary research in the anthropology of money and finance}

Recent anthropological research in this area has partly followed the paths set by the classics. Some anthropologists still try to link local situations to global history through a grand narrative that would encompass all humanity. The idea that "Western" money has unified and colonized the world has, however, been undermined by a flood of demonstrations that money is more multiple and labile than either its supporters or critics suppose. At the same time, the finance industry itself has become a focus of anthropological attention, even though ethnographic findings are still only weakly linked to the global politics of financial flows. New approaches, avoiding grand narratives but integrating global processes and regional research (e.g. Guyer 2004), point to how the anthropology of money might begin to redress this situation. 
What is money? Where does it come from?

Is money an object or an idea, real or virtual? One thing or many? Historically specific or a human universal? Is it a creature of markets or states, or both? Is it credit or debt, or both? Is money impersonal or personal, or both? If it is what it does, which function is most important - medium of exchange, means of payment, unit of account, or store of wealth? Many anthropologists still use the word "money" without saying what they mean by it. Perhaps this is not so remarkable after all. Money is the ocean we all swim in. Whenever did fish make an object of their world? It is not our aim in this review of contemporary research on money to provide definitive answers to these questions; but we should at least indicate where we start from.

It would seem that few anthropologists today (Hart 2005a; Graeber 2011) accept the story that has entered western folklore since Adam Smith (1961 [1776]) invented it. Individuals began by exchanging things they had and others needed for what they themselves needed and others had. Money made the barter more efficient by offering a commodity that would be widely accepted later. This origin myth assumes private property from the beginning: all that is missing from primitive markets is the money. Monetary theorists in Europe since the nineteenth century have opposed this view of money as a product of individual exchange to one where it is the sole creation of the state (Ingham 2004). Here the emphasis is on money as a means of payment (of taxes in particular) and as a standard measure of credit and debt. Monetary policy in the last half century has swung violently between these two extremes.

According to Keith Hart (1986), coins are two-sided for the good reason that political authority and market exchange are both indispensable to money. It is at once a credit token linking persons in society (heads) and a measure of commodities circulating in impersonal markets (tails). David Graeber (2001, 2009, 2011), in a unique historical synthesis, links 
money to debt. The invention of money 5,000 years ago allowed moral obligations to be given an impersonal measure. Its name was debt and violence was the midwife of its birth. World history since then has seen money oscillate between two poles, virtual credit and currency, often coinage made from precious metals.

We have already seen that Mauss and Polanyi saw money as a means of extending the economic reach of local societies that generally aspired to self-sufficiency. In this sense money and the markets it sustains are human universals, although they take many forms different from those with which we are familiar. Polanyi (1977) noted that the modern money form, national monopoly currencies ("all-purpose money"), was invented in the midnineteenth century; and we now know that it has been unravelling since the 1970s. In this regard, several anthropologists have shown that state-building depends on articulating domestic monetary policy with global financial flows (Maurer 2004; Neiburg 2006; Peebles 2008; Holmes 2009).

Meanwhile, Viviana Zelizer (1994), a sociologist whose work has great affinity with ours, has shown that money is given multiple meanings in the United States that go well beyond the expectations of liberal and statist theories. Money is central to relations with high emotional content, such as giving a present to a child, settling a divorce dispute or buying a life insurance contract. Money only comes into existence through these social relations, in that it always make sense within specific social identities, as a means of articulating family ties (Zelizer 2005) or the context of life and death (Zelizer 1979).

This snapshot of the field indicates the pluralism of contemporary anthropological approaches to money, especially our openness to dialectical and partial approaches. There remains, however, the question of the ocean itself and here we must overcome a legacy of top down world histories that tell just one story. 
As early as the 1950s, some anthropologists, notably Paul Bohannan (1955, 1959, see also Polanyi 1957), developed the idea that "Western" or "modern" money was imposing its disruptive rules and social hierarchies on "traditional" societies in the colonial context. Bohannan's analysis has since been shown to be factually wrong, historically misleading and theoretically naïve: far from being a one-sided process, the integration of sterling or dollars into local economies created new uses for money that also reflected the internal workings of those societies (Parry \& Bloch1989; Akin \& Robbins 1999; L'Homme 2002). Yet these critiques accepted that "Western" money was indeed "modern" in ways that were usually left unstudied (Maurer 2005a, 2006, 2012; Hart \& Maurer 2009).

The conversion of the world economy from the Bretton Woods system of managed exchange rates to a "neoliberal" dispensation allowed finance to escape from national production and politics and to invade all areas of social life in a process known as "financialization" (Epstein 2005). This historical shift has supported another wave of grand narratives, often but not always drawing on Marxism (Gregory 1997, Harvey 2005). Lee and LiPuma (2004) studied the rise of derivatives in foreign exchange markets. Their framework, however, led them to consider these new developments as simply another instance of financial capitalism's encroachment on the rest of the world (with its "fictitious" money). David Graeber's (2011) book on debt covers the whole world and many historical moments in a fashion that recalls Max Weber. He identifies three moral forms of economic relations - everyday communism (sharing), exchange (reciprocity) and hierarchy (inequality) - that are combined with varying emphasis throughout human history. But, like Marxist approaches and theories of the Great Divide, his universal history of money does not sit easily with recent research showing how the uses and meanings of money in everyday life are much more multiple and fluid than can be captured by any grand narrative, however encyclopedic its sources. Drawing on Weber 
more explicitly, Arjun Appadurai (2012) has also recently launched a project to reinvent social theory through studying the finance industry in terms of a new "spirit of calculation" (2012); but this too is likely to run up against similar limits in time.

\section{The ethnography of finance and the politics of distribution}

Many ethnographers, drawn from sociology, cultural studies and science studies as well as from anthropology, have shown how the workings of finance in different settings often have little to do with the neoliberal ideology that has justified its recent rise to global dominance. Mitchel Abolafia (1996) revealed how the pits of the New York Stock Exchange were organized by local rules that sought an implicit balance between competition and collaboration among employees (also Baker 1986). Olivier Godechot (2008) likewise identified a "hold-up" strategy for traders to secure high salaries and bonuses by threatening to leave the company along with its proprietary trading software. The behavior of this financial labor aristocracy is hard to square with received theories of "exploitation". These studies challenge the idea that money and finance can be organized by a single set of rules, that they are "Western" in any meaningful sense and that they conform to the model of labor relations that underpins Capital.

If finance occupies a special place in the anthropology of money today, it is because the industry now plays a disproportionate role in allocating wealth around the world. This was made possible by regulatory changes in the 1970s and 80s and supported by neoliberal claims that independent investors meeting in efficient markets mediated by financial professionals would ensure a globally optimal distribution of resources (Abdelal 2007; Krippner 2011). The gap between these abstract premises of financial regulation and how they are implemented in practice has been pointed out by numerous researchers. 
Financial professionals operate in a bureaucratic world, where they are expected to embody the figure of the investor by following stringent and often contradictory rules (Clark \& Thrift 2005). These routinely depart from the ideal of "freedom" of exchange that underpins the neoliberal model (Zaloom 2006; Preda 2009; Ortiz 2014). The methods used for making valuations and investments rest on intellectual traditions for which the theological notion of infinity is central (Maurer 2002); and positivist constructions of the relationship between natural law and mathematics (De Goede 2005) are used to determine stock indexes or the "financial value" of futures and credit derivatives (Tett 2009; Ortiz 2013). The usefulness of probabilistic models of risk has been questioned by Ayache (2010), following Meillassoux (2010); but these still significantly shape the economy because they are an essential part of everyday practice in the rating agencies (Ouroussoff 2010; MacKenzie 2011). Their adoption is not due to any intrinsic cognitive clarity, which is largely absent (Knorr Cetina 2005; Knorr Cetina \& Preda 2007; Riles 2011; Lépinay 2013). It depends rather, for example, on the strong links forged between academia and the finance industry during the second half of the twentieth century, reinforced by so-called Nobel prizes awarded to economists who promoted the right message (MacKenzie 2006).

None of this criticism appears to disturb the dominant liberal narrative, which continues to shape the finance industry's institutional practices, as Lucia Müller (2006) has shown for Brazil and Karen Ho (2009) for the United States. Even the notion of "financial crisis" has been assimilated to this discourse (Ortiz 2012). Discussions over how prices would be determined by the Euronext software, for example, hinged on whether it would indeed reproduce the true value expected by liberal theory (Muniesa 2000, 2007). Ellen Hertz's (1998) pioneering study showed that the Chinese middle classes embraced stock markets as a way for decentralized investors to check state control. Eventually, this led them to consider 
themselves helpless in the face of "the market", allowing the state to retain much of its power.

Several anthropologists have shown that citizenship itself is shaped by the debates over monetary policy (Hart 1986). Identification of citizenship with owning a home, while hiding the US economy's dependence on global credit supplies, underpinned the monetary policy that led to the subprime mortgage crisis there (Jorion 2007). The ideology that currencies are state-made is contradicted by many studies of proliferating currencies produced by other bodies. These can include complementary currencies with transnational circulation or Islamic finance influenced by moral and/or religious narratives that oppose national identity or simply differ from it (Zelizer 1998, Maurer 2005b, Hart 2006).

\section{Bringing world history back in}

Although most ethnographers of finance start from the premise that they are studying global processes, their rich results are limited by usually being able only hint at this as a general horizon or perhaps to pinpoint some particular aspect. Grand narratives have the illusory benefit of allowing a situated observation to speak for a world conceived of as being unitary. Analyzing money and finance through its multiple local practices does not permit such a step. After Nader's (1972) call to study up and Appadurai's (1986) injunction for us to approach global economic transactions through the meanings that people give to them, some anthropologists have sought to show how the plurality of practice might be unified without being reduced to a single narrative.

Keith Hart (2000, 2005b) has explored how personal uses of money might be incorporated into an analysis that takes into account the role of transnational corporations, state control of 
money and the rise of new digital media. Here any unifying perspective comes not from an objectifying narrative that would explain everything, but from a moral and political question: how might each person's experience of money in their daily life be related to massive global inequalities in the distribution of money? One immediate conclusion is that several processes take place at the same time, competing with and influencing each other. Nigel Dodd (2005, 2014) agrees: only by approaching money as a labile social relation with rules that change can we address money's multiplicity at the global level, seeing it as a product of several histories that join and part, in an increasingly interconnected world.

Jane Guyer (2004) has demonstrated how this can be done in practice, thereby opening up new methodological horizons for the study of money. Based on long-term participant observation and archival research, she shows that Atlantic Africans developed a plural framework for commerce, where social rank, multiple scales of monetary valuation and circuits of exchange intersect and diverge. Her historical analysis takes in indigenous developments, reactions to imperialism and global economic ties after independence. Guyer contrasted this flexible regional culture with the reductive oversimplifications of economic historians and the parochialism of local ethnographers. But she has subsequently (Guyer 2010, 2012) extended her reach to include monetary practices in the contemporary United States and in British economic history. In the process she is discovering that the European sailors and traders who first encountered Atlantic Africa brought with them commercial practices that were closer to the indigenous model than to any that we have imputed to them after the fact. Guyer's outstanding achievement is that she has been able to describe and explain how new monetary relations are created without resorting to a single overarching narrative of what money is. 


\section{The way forward for an anthropology of money and finance}

Finally, we propose a reflexive strategy for the anthropology of money and finance grounded in the pragmatic approach that we have outlined so far. Our own analytical categories, conceptual assumptions and normative propositions are part of the object that we study. This presents both a challenge and an opportunity.

The need to combine fieldwork methods with historical study of global processes

Ethnographic fieldwork generates knowledge of the regularities and changes of everyday life. But when it comes to money and finance, whatever we study is part of exchange networks that go far beyond the limits of our observations. The whole point of markets is that their extent is unknowable and beyond effective local control. Not only do social interactions proliferate beyond our gaze, but so too do the concepts and narratives that people use to make sense of them. The first step in linking everyday practices to the global contexts that make them understandable is historical comparison. We illustrate this point with regard to the categories of economic and financial theory and to the alleged contrast between state-made money and citizenship in the West and the rest.

Much ethnography of finance focuses on cognitive aspects of the situations observed, as if knowledge production were the firms' principal objective. We learn how barriers to the communication of information challenge the regulators' assumptions concerning "efficient" markets and the optimal allocation of resources. But in these studies, we rarely discover where the money goes and in what quantities, yet these are businesses, not academic departments. An inability to examine the relationship between money and knowledge reflexively risks reproducing the finance industry's own vision of itself. The same is true of unreflecting use of categories such as "investors" and "markets" (Ortiz 2014). In recent talk 
of the "crisis", it has passed largely unnoticed that, according to financial regulations, the term refers to the temporary failure of "markets" without ever questioning their long-term "efficiency". Moreover, the financial crisis looks very different when viewed from countries, like China and Brazil, where economic conditions improved recently or the Democratic Republic of Congo where conditions remain catastrophic without ever attracting the investment interest that fuelled real estate speculation in the United States (Jorion 2007, Hart 2012, Ortiz 2012). Rather than repeat the categories of financial theory and regulation without reflexivity, anthropologists need to investigate their intellectual history more critically (De Goede 2005, MacKenzie 2006, Preda 2009).

The Great Divide still beggars investigation of the state's role in the production of money. Hegel's (1821) idea of the state bears little resemblance to the variety of forms that go by that name today. Yet the West, which supposedly invented money in the form of national monopoly currency, is routinely contrasted with the rest who must adopt the "modern" model by means of colonization or rationalization (Hart 2000, Guyer 2004). Yet anthropologists have shown that state formation in Caribbean offshore islands requires them to adopt a form of sovereignty that leaves them open to global financial flows (Maurer 2004), while the Chinese state seeks to control its citizens through regulating participation in financial markets (Hertz 1998). By placing fieldwork observations within a framework of global comparison anthropologists can promote different views of the state and its relation to money.

Too often, anthropologists acknowledge the centrality of history, but leave it out of their descriptions and analyses. Thus, even when analyzing colonial relations, the contributors to (Parry \& Bloch 1989) assumed the global context away in order to concentrate on their local objects of study. Global networks usually appear in ethnographies of finance, if at all, only as an implicit abstraction. Like media accounts of the financial crisis, most ethnographers 
conflate local events with 'the world' (Ortiz 2012). Labelling everything 'neoliberalism' is likewise a poor substitute for studying world economy. Mauss (1990) made a pointed contribution to debates about income distribution and inequality in France by highlighting how reciprocity traverses hierarchy in the Northwest Coast potlatch, the kula ring and ancient Teutonic law. He saw the bedrock of all human morality in his comparisons. But he also generated analytical categories broad and deep enough for us to say something different about present times.

\section{States, corporations and regional associations}

Money, first as precious metals and lately in paper and electronic forms, has been long guaranteed by what Weber (1978) called the state's "monopoly of the use of legitimate violence". But it only took the form of a national monopoly in the mid-nineteenth century, reaching its apogee after the Second World War, and has been decomposing since the end of the Bretton Woods agreements in 1971 (Galbraith 1975; Eichengreen 1996; Hart 2012). 'National capitalism' (Hart 2009) is the modern synthesis of the nation-state and industrial capitalism, the institutional attempt to manage money, markets and accumulation through central bureaucracy within a cultural community of national citizens. The nation-state has dominated thinking about society since the mid-nineteenth century, even though society has long been leaking across its boundaries, and money is its most powerful symbol. But the 'non-contractual element in the contract' (Durkheim 1960) is no longer sustained by national frameworks alone. The single-currency model of national economy is being extended to become a more plural, federal assemblage, thereby creating new forms of inclusion and conflict. Regional associations, whatever the limitations of their design, are already a step in this direction. The International Financial Institutions (IFIs) are in search of a new Bretton Woods, as the Beijing Consensus attempts to challenge the Washington Consensus in a multi- 
polar geopolitics; and bottom-up approaches to building world institutions afresh are claiming a share of the political design (Pleyers 2010).

National governments are being sidelined by international and regional organizations, such as ASEAN, the Chiang Mai agreements supporting foreign exchange stability in East Asia, Mercosul or the European Union with its eurozone. East African governments are discussing tax unions to deal with Chinese trade. United Nations bodies, the IMF, the World Bank, the World Trade Organization and the International Organization of Security Commissions all still claim to derive their legitimacy from states. But their specific areas of competence sustain a global network of decision-making that no single state can control on its own.

The rise of European states cannot be understood outside their symbiotic and conflicting relations with corporations and global financial institutions. Global corporations, still called "multi-national" due to their ambiguous allegiance to state-made laws, articulate global flows of money that far surpass the capacity of any state to control them. They create their own monetary instruments (Zelizer 1994) and, while retaining limited liability for debts, they benefit from the legal rights and moral personhood accorded individual citizens, despite their much greater wealth, power and longevity (Hart 2005b). They are redrawing the concept of citizenship around the world. Anthropologists have been slow to grasp the dynamics of a world economy where these corporations seek to control all stages from research and development, through production, regulation, distribution and marketing to household consumption (Applbaum 2004).

Finance, communications technologies and new forms of money

The progressive collapse of the gold standard in the twentieth century has been accompanied by the extension of mass communications: first radio, TV and cinema, lately the internet and cellular phones. This is fundamental to the finance industry and its crises, as well as to global 
tensions over trade and currencies. New communication technologies have changed how billions relate to humanity at every level from the most intimate to the most inclusive. Allpurpose money (Polanyi 1977) has been breaking up since the US dollar went off gold in 1971 (Dembinski \& Perritaz 2000). World economy has been moving towards a new plural pattern of competing currencies reminiscent of what was normal before the advent of national capitalism. The finance industry produces restricted monies and forms of credit that mix with national currencies, reinforcing and weakening them. Like state-money since the gold standard ended, other money forms are emerging, based on communications networks, multiple institutions and mutual trust.

Thanks to the communications revolution, foreign exchange markets now turn over $\$ 4$ trillion a day, while the capitalization of markets for stocks and bonds far exceeds global output. The volume of information now circulating in real time through the Internet's cables and satellites was unthinkable less than a century ago. Along with the mass media, this has allowed the whole world to enter people's homes and to inform daily transactions everywhere. This technological revolution has not just reinforced centralized institutions like the banks and governments. It has allowed everyday life to be linked to the world economy through money (Hart 2000). Since the millennium, we have seen an explosion of the social media (Web 2.0) and a shift towards the use of mobile phones for computing operations and increasingly for monetary transactions. The internet never had a built-in means of payment, but mobile phones do (Agar 2004; Horst \& Miller 2006).

Finally, proliferating alternative currencies now create different forms of monetary sovereignty and educate participants in new ways of thinking about monetary possibilities and social justice (Zelizer 1998; Maurer 2005b; Hart 2006). A single-minded focus on 
national currencies misses entirely the windows on global distribution that these experiments open up.

\section{Money in the making of society at all levels}

Where are the levers of democratic power to be located, now that globalization has exposed the limitations of national economic management? The current crisis challenges contemporary financial ideas, while its tangible distributive effects are felt and feared throughout the world. We are witnessing a power struggle of awesome consequences and economic anthropologists cannot afford to stand to one side. Rather than support our proposals with a single story, we start from the multiple ways that human beings have already inserted themselves into existing unequal society which should inform new developments in the human economy (Pleyers 2010, Hart, Laville and Cattani 2010).

Anthropologists have gained immensely from exploring the capitalist heartlands, but we must still aspire to a wide range of geographical knowledge. An economic anthropology that limits itself to ethnographic studies of stockbrokers or traders will never grasp humanity's shared economic predicament. By studying monetary relations on different geographical scales, from intimate encounters to foreign exchange markets, anthropologists can help create new meanings and connections between our everyday life and the seven billion people with whom we share it.

Through the internet or phone network, we can span now the world and connect personally with people whom we will never meet. Humanity has at last found universal media for the expression of universal ideas. Money is essential to their dissemination. It is a constitutive part of our multiple-layered identities, from the most intimate relations to communities of exchange on a vast scale. Money allows us to express ourselves and indexes our place in 
hierarchies, solidarities and enclosures. Our identities expand, fragment and recombine as we move from the most local transactions to national or regional currencies. Central banks, insurance companies, pension funds, global and local banks, savings clubs and other local credit schemes, all shape the possibilities for our personalities to develop. We learn about politics and our membership of larger groups by participation in monetary networks that exclude and entrap us even as they extend our horizons. As Mauss saw, the notion of society itself is reshaped by this multifarious expansion. If we hope for a more peaceful and integrated world society, money will certainly play an important role in its formation.

\section{References}

Abdelal R. 2007. Capital Rules. The Construction of Global Finance. Cambridge, M.A.: Harvard University Press

Abolafia M. 1996. Making Markets: Opportunism and restraint on Wall Street. Cambridge MA: Harvard University Press

Agar J. 2004. Constant Touch: A global history of the mobile phone. London: Faber \& Faber.

Akin D, Robbins J (eds.) 1999. Money and Modernity: State and local currencies in Melanesia. Pittsburgh: University of Pittsburgh Press

Appadurai A. 1986. The Social Life of Things: Commodities in cultural perspective. Cambridge: Cambridge University Press

Appadurai A. 2012. The spirit of calculation, Cambridge Anthropology (30)1: 3-17

Applbaum K. 2004. The Marketing Era: From professional practice to global provisioning. New York: Routledge

Ayache E. 2010. The Blank Swan: The end of probability. New York: Wiley

Baker W E 1986. Floor trading and crowd dynamics. In The Social Dynamics of Financial Markets, ed. P Adler, P A Adler, pp. 107-128. Greenwich, Connecticut: JAI Press Inc

Bohannan P. 1955. Some principles of exchange and investment among the Tiv of Central Nigeria. Am. Anthropol. 57: 60-70

Bohannan P. 1959. The impact of money on an African subsistence economy. Journal of Economic History 19: 491-503 
Clark G, Thrift N. 2005. The Return of Bureaucracy: Managing Dispersed Knowledge in Global Finance. In The Sociology of Financial Markets, ed K Knorr Cetina, A Preda, pp. 229-49. Oxford: Oxford University Press

De Goede M. 2005. Virtue, Fortune and Faith. A Genealogy of Finance. Minneapolis, London: University of Minnesota Press.

Dembinski P, Perritaz C. 2000. Towards the break-up of money. When reality driven by information technology outshines Simmel's vision. Foresight: Journal of Future Studies, Strategic Thinking and Policy (2)5: 483-97

Dodd N. 2005. Laundering money: on the need for conceptual clarity within the sociology of money. European Journal of Sociology (44)3: 387-411

Dodd N. 2014. Laundering Money. Princeton NJ: Princeton University Press. Forthcoming

Durkheim E. 1960 [1893]. The Division of Labor in Society. Glencoe IL: Free Press

Durkheim E. 1965 [1912]. The Elementary Forms of the Religious Life. Glencoe IL: Free Press

Eichengreen B. 1996. Globalizing Capital. A History of the International Monetary System. Princeton: Princeton University Press

Epstein G. 2005. Financialization and the World Economy. Cheltenham: Edward Elgar

Fournier M. 2006 [1994]. Marcel Mauss: A Biography. Princeton NJ: Princeton University Press

Galbraith J K. 1975. Money: Whence it came, where it went. New York: Penguin Books

Godechot, O. 2008, "Hold-up" in finance: the conditions of possibility for high bonuses in the financial industry. Revue française de sociologie, Supplement Annual English Edition, 49: 95123

Graeber D. 2001. Toward an Anthropological Theory of Value. The False Coin of Our Own Dreams. New York: Palgrave

Graeber D. 2009. Debt, violence, and impersonal markets: Polanyian meditations. In Market and Society: The Great Transformation Today, ed C Hann, K Hart, pp. 106-32. Cambridge: Polity

Graeber D. 2011. Debt: The First 5,000 Years. New York: Melville House

Gregory C. 1997. Savage Money: The anthropology and politics of commodity exchange. Amsterdam: Harwood

Guyer J I. 2004. Marginal Gains. Monetary Transactions in Atlantic Africa. Chicago, IL: Chicago University Press.

Guyer J I. 2010. The Eruption of Tradition? On Ordinality and Calculation. Anthropological Theory 10: $123-31$

Guyer J I. 2012. Soft Currencies, Cash Economies, New Monies: Past and Present. Proceedings of the National Academy of Sciences 109(7): 2214-21 
Hann, C. and Hart, K. 2011. Economic Anthropology: History, Ethnography, Critique. Cambridge: Polity

Hart K. 1986. Heads or tails? Two sides of the coin. Man (21)3: 637-56

Hart K. 2000. The Memory Bank: Money in an Unequal World. London: Profile; republished in 2001 as Money in an Unequal World. New York: Texere.

Hart K. 2005a. Money: one anthropologist's view. In Handbook of Economic Anthropology, ed. J Carrier, pp. 160-75. Cheltenham: Edward Elgar

Hart K. 2005b. The Hit Man's Dilemma: Or Business, Personal and Impersonal. Chicago: Prickly Paradigm Press.

Hart K. 2006. Richesse commune: construire une démocratie économique à l'aide de monnaies communautaires. In Exclusion et liens financiers - Monnaies Sociales: Rapport 2005-6, ed. J Blanc pp. 135-52. Paris: Economica

Hart K. 2007. Marcel Mauss: In pursuit of the whole: a review essay. Comp. Stud. Soc. Hist. 49(2): 473-485

Hart K. 2009. Money in the making of world society. In Market and Society: The Great Transformation today, ed. C Hann, K Hart pp. 91-105. Cambridge: Cambridge University Press

Hart K. 2012. The financial crisis and the history of money. In Handbook of Economic Anthropology: Second Edition, ed. J Carrier, pp. 626-37. Cheltenham: Edward Elgar

Hart K. 2014. See 2010. Mauss et sa vision économique dans les années 1920-1925. In Mauss Vivant. Revue du MAUSS N³6, ed. A Caillé, P Chanial, K Hart pp. 34-48

Hart K, Laville J, A D Cattani A D, eds. 2010. The Human Economy: A Citizen's Guide. Cambridge: Polity

Hart K, Maurer B. 2009. The politics, pragmatics and promise of money. http://thememorybank.co.uk/2009/11/21/conversation-about-money/

Harvey D. 2005. A Brief History of Neoliberalism. Oxford: Oxford University Press

Hegel G W F. [1821] 1967. The Philosophy of Right. Oxford: Oxford University Press

Hertz E. 1998. The Trading Crowd: An Ethnography of the Shanghai Stock Market. Cambridge: Cambridge University Press

Ho K. 2009. Liquidated: An Ethnography of Wall Street. Durham: Duke University Press

Holmes D. 2009. Economy of Words. Cultural Anthropology (24)3: 381-419

Horst H, Miller D. 2006. The Cell Phone: An anthropology of communication. Oxford: Berg

Ingham G. 2004. The Nature of Money. Cambridge: Polity Press

Jorion P. 2007. La crise du capitalisme américain. Paris: La Découverte 
Knorr Cetina K. 2005, How are Global Markets Global? The Architecture of a Flow World. in The sociology of financial markets, eds. K Knorr Cetina, A Preda, pp. 38-61. Oxford: Oxford University Press

Knorr Cetina K., Preda, A. 2007. The Temporalization of Financial Markets: From Network Markets to Flow Markets. Theory, Culture and Society 24(7-8): 123-45

Krippner G R. 2011. Capitalizing on Crisis. The Political Origins of the Rise of Finance. Cambridge: Harvard University Press

Lépinay V A. 2011. Codes of Finance. Engineering derivatives in a global bank Princeton: Princeton University Press

L'Homme, 2002, $\mathrm{n}^{\circ}$ 162, avril/juin.

c

MacKenzie D. 2006 An Engine not a Camera. How Financial Models Shape Markets. Cambridge, MA: MIT Press

MacKenzie D. 2011. The credit crisis as a problem in the sociology of knowledge. Am. J. Soc. (116)6: $1778-841$

Malinowski B. 1921. The primitive economics of the Trobriand Islanders. Economic Journal 3: 11-16

Malinowski B. 1922. Argonauts of the Western Pacific: An Account of Native Enterprise and Adventure in the Archipelagos of Melanesian New Guinea. London: Routledge \& Kegan Paul

Marx K. 1973 [1858]. Grundrisse. Foundations of the critique of political economy. New York: Vintage Books

Marx K. 1977 [1869], Capital. A Critique of Political Economy. Vol. 1. Tr. B Fowkes. New York: Vintage Books

Marx K, Engels F. 1987 [1848]. The Communist Manifesto. New York: Pathfinder Press

Maurer B. 2002. Repressed futures: financial derivative's theological unconscious. Econ. Soc. (31)1, February: $15-36$.

Maurer B. 2004. Cyberspatial Properties: Taxing Questions about Proprietary Regimes. In Property in Question. Value transformation in the global economy, eds. C Humphrey, K Verdery, pp. 297318. New York: Berg

Maurer B. 2005a. Finance. In Handbook of Economic Anthropology, ed. J Carrier, pp. 176-93. Cheltenham: Edward Elgar

Maurer B. 2005b. Mutual Life, Limited: Islamic Banking, Alternative Currencies, Lateral Reason. Princeton NJ: Princeton University Press

Maurer B. 2006. Anthropology of Money. Annu. Rev. of Anthropol. 35: 15-36 
Maurer B. 2012. Finance 2.0. In Handbook of Economic Anthropology: Second Edition ed. J Carrier, pp. 183-201. Cheltenham: Edward Elgar

Mauss M. 1990 [1925]. The Gift: The Form and Reason for Exchange in Archaic Societies. London: Routledge

Mauss M. 1985 [1938]. A category of the human mind: the notion of person; the notion of self. Tr. W D Halls. In The Category of the Person: Anthropology, philosophy, history, eds. Carrithers, M., S. Collins and S. Lukes, pp. 1-25. Cambridge: Cambridge University Press

Mauss M. 1997. Écrits politiques, ed. M Fournier. Paris: Fayard

Meillassoux Q. 2010. After Finitude: An essay on the necessity of contingency. London: Continuum

Müller L. 2006. Mercado Exemplar: um estudo antropológico sobre a Bolsa de Valores. Porto Alegre: Editora Zouk

Muniesa F. 2000. Un robot walrasien. Cotation électronique et justesse de la découverte des prix. Politix (13)52: 121-54

Muniesa F. 2007. Market technologies and the pragmatics of prices. Econ. Soc. (36)3: 377-95

Nader L. 1972. Up the Anthropologist - Perspectives Gained from Studying Up. In Reinventing Anthropology, ed. D Hymes, pp. 284-311. New York: Pantheon Books

Neiburg F. 2006. Inflation: Economists and Economic Cultures in Brazil and Argentina. Comp. Stud. Soc. Hist (48)3: 604-33

Nishibe M. 2005. The theory of labor money: implications of Marx's critique for Local Exchange Trading Systems (LETS). In Marx for the $21^{\text {st }}$ century, ed. H. Uchida, pp. 89-105. London: Routledge

Ortiz H. 2012. Anthropology - of the financial crisis. In Handbook of Economic Anthropology: Second Edition, ed. J Carrier, pp. 585-96. Cheltenham: Edward Elgar

Ortiz H. 2013a. Financial value: economic, moral, political, global. Hau. Journal of Ethnographic Theory 3 (1): 64-79

Ortiz H. 2013b. Financial professionals as a global elite. In The Anthropology of Elites, eds. T Salverda, J Abbink, pp. 185-205. New York: Palgrave

Ortiz H. 2014. The Limits of Financial Imagination: Free Investors, Efficient Markets and Crisis. Am. Anthropol. (116) 1. In press

Ouroussoff A. 2010. Wall Street at War. Cambridge: Polity

Parry J, Bloch, M, eds. 1989. Money and the Morality of Exchange. Cambridge: Cambridge University Press

Peebles G. 2008. Inverting the Panopticon. Money and the Nationalization of the Future. Public Culture (20)2: 233-65 
Pleyers G. 2010. Alter-globalization: Becoming actors in a global world. Cambridge: Polity

Polanyi K. 2001 [1944]. The Great Transformation: The Political and Economic Origins of Our Times. Boston MA: Beacon

Polanyi K. 1957. The economy as instituted process. In Trade and Market in the Early Empires: Economies in History and Theory, eds. K Polanyi, C Arensberg, H Pearson, pp. 243-69. Glencoe IL: Free Press

Polanyi K. 1977 [1964]. Money objects and money uses. In Polanyi K. 1977. The Livelihood of Man. Studies in Social Discontinuity, pp. 97-121. New York: Academic Press

Preda A. 2009. Framing Finance: The Boundaries of Markets and Modern Capitalism. Chicago and London: University of Chicago Press

Riles A. 2011. Collateral Knowledge. Legal Reasoning in the Global Financial Markets. Chicago and London: University of Chicago Press

Simmel,G. 1978 [1900]. The Philosophy of Money. London: Routledge

Smith A. 1961 [1776]. An Inquiry into the Nature and Causes of the Wealth of Nations. London: Methuen

Tett G. 2009. Fool's Gold: How the Bold Dream of a Small Tribe at J. P. Morgan Was Corrupted by Wall Street Greed and Unleashed a Catastrophe. New York: Free Press

Weber M. 2003 [1904-1905]. The Protestant Ethic and the Spirit of Capitalism. Tr. T Parsons. Mineola, New York: Dover Publications Inc

Weber M. 1978 [1920]. Economy and Society. An Outline of Interpretive Sociology. Tr. E Fischoff et alii, eds. G Roth, C and Wittich. Berkeley: University of California Press

Weber M. 2013 [1922]. General Economic History. Tr. F Knight. Martino Fine Books

Zaloom C. 2006 Out of the Pits: Traders and Technology from Chicago to London. Chicago: University of Chicago Press

Zelizer V. 1979. Morals and Markets: The development of life insurance in the United States. New York: Columbia University Press

Zelizer V. 1994. The Social Meaning of Money. New York: Basic Books

Zelizer V. 1998. The proliferation of social currencies. In The Laws of the Markets, ed. M Callon, pp. 58-68. Oxford: Blackwell Publishers

Zelizer V. 2005. The Purchase of Intimacy. Princeton and Oxford: Princeton University Press 